\title{
Bcecbimur icmopia
}

\author{
Євген Хвальков \\ ORCID iD 0000-0003-3688-7638
}

УДК 94:327(560+262.5)"1400/1475"(1-52)

DOl: 10.28925/2524-0757.2019.2.7

\section{ГЕНУЕЗЬКІ ТА ВЕНЕЦІЙСЬКІ КОЛОНІЇ ПРИЧОРНОМОР'Я І ПРИАЗОВ'Я В ПОЛІТИЦІ ТА МІЖНАРОДНИХ ВІДНОСИНАХ (1400-1475)}

Наприкінці середньовіччя регіон Чорного моря став зоною, яка набувала все більшого політичного значення. У XIV-XV cm. тут стикалися інтереси численних політичних гравців: Генуезька, Венеційська, Флорентійська і Пізанська республіки, Папський Рим, Священна Римська імперія, Англійське, Французьке й Арагонське королівства, Герцогство Бургундія, Візантійська імперія, Грузія, Велике князівство Литовське, Королівство Польське, Угорщина та Валахія і, нарешті, зростаюча Османська імперія. Однак ані сама метрополія, ані ї̈ союзники не могли допомогти Кафі, яка разом з іншими генуезькими та венеціанськими колоніями була захоплена османами під командуванням Гедик Ахмет-паші в 1475 рочі. Згодом весь регіон Південно-Східної Європи опинився під домінуванням Османської імперії.

Ключові слова: Генуя, Кафа, колонії, Кримське ханство, Східне Середземномор'я, Чорне море.

\section{Evgeny Khvalkov}

THE GENOESE AND VENETIAN COLONIES IN THE BLACK SEA AND THE AZOV SEA AREAS IN POLITICS AND INTERNATIONAL RELATIONS (1400-1475)

At the end of the Middle Ages, the Black Sea region became an area of increasing political importance. In the 14th and 15th centuries in this region (the Black Sea and the Azov Sea) and even in the regions of Southeastern and Eastern Europe, the interests of numerous political players were confronted: Genoa, Venice, Florence and Pisa, Vatican, the Holy Roman Empire, the kingdoms of England, France and Aragon, the Duchy of Burgundy, the Byzantine Empire, Georgia, Russian principalities, Tatar states, the Grand Duchy of Lithuania, the Kingdom of Poland, Hungary and Wallachia, the Mamluk Sultan and, finally, the growing Ottoman Empire were just a short list of actors on the political scene at that time. However, against the background of the growing Ottoman threat, neither the metropolis of the colonies itself, Genoa, nor Casimir IV, the King of Poland and Grand Duke of Lithuania, nor Vladislaus II, the King of Bohemia and of Hungary, who was also an enemy of the Ottomans, could help Caffa. Caffa and other Genoese and Venetian colonies were captured by the Ottomans in 1475. Thus, we can see that there were numerous wars in Southeastern Europe in the fifteenth century, which eventually led to the domination of the Ottoman Empire.

Key words: Genoa, Caffa, colonies, Crimean Khanate, Eastern Mediterranean, Black Sea.

( С Київський університет імені Бориса Грінченка, 2019

(с) Хвальков $\epsilon$., 2019

$\Pi$ 'ятнадцяте сторіччя стало поворотним моментом у європейській історії, особливо в Середземноморському та Чорноморському регіонах. Османська експансія на Балканах і в Малій Азії, агонія Візантії, розвал Золотої 
Орди, татарські зіткнення та суперечки в степах, змінивши баланс сил у районі Чорного моря, почали обмежувати доступ Заходу до Сходу (Thiriet F., 1959. Р. 141). Східне Середземномор'я та Чорноморський регіон стали одним із центрів міжнародних відносин, де різноманітні актори й агенти стикалися, об'єднувалися, зраджували, перемагали та програвали. Лише короткий перелік гравців на політичній арені того часу вражає: Генуезька, Венеційська, Флорентійська і Пізанська республіки, Папський Рим, Священна Римська імперія, Англійське, Французьке й Арагонське королівства, Герцогство Бургундія, Візантійська імперія, Грузія, руські князівства, татарські держави, Велике князівство Литовське, Королівство Польське, Угорщина та Валахія, мамлюкські султани Єгипту, незначні мусульманські монархи Малої Азії і, нарешті, зростаюча Османська імперія. Поряд із цими великими акторами треба розглядати місцеві політичні сили, як-от: новий окремий Кримський ханат, Трапезундська імперія або Князівство Феодоро, яке, попри свій другорядний статус на європейській політичній карті, було чималою перешкодою генуезькій політиці в Криму й важливим союзником Венеційської республіки.

Політичні зміни, викликані османською експансією, вплинули, зокрема, на італійські колонії за кордоном. Це був час війн і заворушень, комерційних підприємств і велетенських втрат, інтриг і масових убивств, католицьких місіонерів і релігійних військових порядків, внутрішньої боротьби політичних еліт у Генуї і Венеції, успішного мусульманського джихаду і невдалої спроби останніх хрестових походів латинського християнства проти ісламу. Але як Генуезька i Венеційська колоніальні імперії на берегах Чорного моря, так і ї багатокультурне колоніальне суспільство підлаштовувалися до жорсткої політичної ситуації, створеної османським розширенням i переміщенням торговельних шляхів. Метою статті $€$ відповідь на запитання: як саме політико-економічна ситуація, що склалася, впливала на життєдіяльність Генуезької та Венеційської колоніальних імперій і яку роль вони відігравали у політичному неспокої того часу?

У латинському християнському світі i, зокрема, у Східній Європі порядок денний в 1420-х роках складався з Антиосманської ліги. Це збігалося з прагненнями Візантії, яка хотіла об'єднати Венецію і Угорщину проти османів та польського короля (Nicol D., 1988. P. 364). 3 цією метою в 1420 р. Мануел Філантропінос виступив посередником між Венецією та Сигізмундом Люксебурзьким, королем Угорщини, відвідавши і короля Польщі Владислава II Ягайло (Barker J., 1969. Р. XXXIII). Угорський чи польський король могли видаватися можливими захисниками християнського світу в Чорноморському регіоні в 1434 р. («Грамота Илиаша воеводы...», 1860. C. 323-330). Сигізмунд Люксембурзький дуже схилявся до союзу; однак його потуги звелися нанівець, оскільки для Генуї і Венеції їх протистояння одне з одним здавалося тоді важливішим за ідею хрестового походу (Tardy L., 1971. Р. 16). Крім того, зростання інтересу Сигізмунда до Чорноморського регіону викликало глибоку стурбованість генуезців, які не бажали, щоб якийсь східноєвропейський князь встановив владу на берегах Чорного моря.

У Венеції 1420-ті роки стали початком нового періоду економічного зростання (Карпов С., 1990. С. 106-108). Відповідно у 1410-х і $1414-$ х роках вона тимчасово зміцнила свої позиції у Східному Середземномор'ї та у європейській політиці взагалі. 29 травня 1416 р. венеційський флот переміг османів біля Галліполі (Barker J., 1969. Р. XXXIII). 30 жовтня 1418 р. був підписаний новий договір між Венецією і Візантією. У 1419 р. Венеція і султан Османської імперії підтвердили венеційські володіння на Сході (Nicol D., 1988. P. 358).

Венеція мала лише дві колонії у Причорномор'ї - Трапезунд і Тану, тому іiі позиція була хиткішою порівняно з генуезькою. 3 іншого боку, венеційці намагалися зберегти ці колонії. Тана і відправлені туди mudae (тобто організовані експедиції галер) мали не тільки значне комерційне, а й величезне політичне значення, тому важко переоцінити важливість Тани для Венеціі. У 1423 р. венеційці додали ще одну перлину до свого Stato da Màr чи Domini da Mar, купивши Салоніки у Візантії (Daru P., 1821. Р. 168) й уклавши новий договір 30 вересня 1423 р. $з$ імператором Іоанном VIII Палеологом

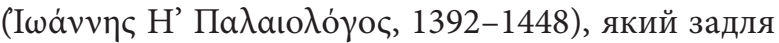
цього спеціально прибув до Венеції (Barker J., 1969. Р. XXXV). У цілому цей договір підтвердив усі привілеї, визнані попередніми договорами від 1390-го, 1406-го і 1418-го років (Nicol D., 1988. Р. 364). Проте проблеми залишалися невирішеними. Після придбання Салонік, багатого торговельного міста, Республіка Святого Марка автоматично опинилася у стані війни з османами (1423-1429) (Daru P., 1821. P. 168). У 1422 p. Мурад II (султан у 1421-1444, 1446-1451 роках) взяв в облогу Константинополь (Nicol D., 1988. Р. 358), відправив армію до Мореї у 1423 р., вирушив у похід на Боснію та Албанію i, зобов'язавши правителя Валахії сплачувати данину, остаточно зайняв венеційські Салоніки в 1430 р. (Ducas, ed. B.G. Niebur, 1834. P. 198; Barker J., 1969. P. 372-374, 384). Відтоді Візантія поступово припиняє бути координаційним центром для венеційців, які почали переходити на територію Терраферми. Крім того, війни в Італії стали пріоритетом для нового дожа Венеції Франческо Фоскарі (1423-1457). 
Зміни в політичній ситуації в Середземномор'ї збіглися зі змінами у степах. Це був час розпаду Золотої Орди (1420-1502). Для італійців це означало лише нестабільність: у степах постійно змінювалися хани, часто кілька претендентів боролися один з одним, маршрути залишалися небезпечними, і татари могли нападати на колонії, коли їм заманеться. У 1423 р. на татарській політичній арені з'явився новий актор - узбецький хан Барак. Він очолив кочівників із Західного Сибіру, здолавши Улуг-Мухаммеда (Oluğ Möxämmät; 1405-1445) - майбутнього засновника Казанського ханства, який був пов'язаний із Вітовтом і потім утік у Велике князівство Литовське просити про допомогу. Однак пізніше він вигнав Барака в Могулістан, де той був убитий у період з 1427-го до 1429-го року. 14 березня 1428 р. Улуг-Мухаммед написав листа султану Мураду II про відновлення дипломатичних відносин. Після поразки Барака в 1427 р. у Криму влаштувався ще один хан - Девлет-Берди (? бл. 1432). Улуг-Мухаммед намагався вдертися до Криму в 1430 р., але після смерті свого покровителя Вітовта він відступив. Тим не менш, ні Девлет-Берди, який був убитий в 1432 р., ні його син Ахмат, якого розгромили у 1433 р., не міг реально керувати Кримом, де місцеві правителі почали поводитися самостійно. Під час протистояння Улуг-Мухаммед перейшов на бік Сигізмунда Кейстутовича (бл. 1365-1440), а Свидригайло (бл. 1370-1452) і московський князь підтримали Саїд-Ахмада I (? - після 1455), третім претендентом на престол Золотої Орди був КучукМухаммед. Баланс сил між трьома ханами (УлугМухаммед, Кучук-Мухаммед і Саїд-Ахмадом) був порушений після того, як Улуг-Мухаммед, номінально вищий правитель, напав на двох інших. Відступивши, він заснував Казанське ханство. Улуг-Мухаммед та його син Махмутек окупували Бельов у 1437 р. і Казань у 1445 р. Відтоді незалежне Казанське ханство почало відігравати важливу роль у Східній Європі.

I сучасники подій, і вчені погоджуються 3 тим, що політику степу і призначення ханів значною мірою контролював великий князь литовський Вітовт. Велике князівство захопило чимало руських князівств і отримало вигоду від розпаду Золотої Орди, а його могутній князь за власним бажанням підтримував або розпоряджався ханами. Дійсно, зберегти татар відокремленими було в його інтересах і в інтересах його держави. У низці літописів, написаних руською, існує довгий панегірик «Похвала Вітовту», який, як і в Kronika polska, litewska, żmódzka i wszystkiéj Rusi Мацея Стрийковського (Kronika polska..., 1846. Р. 156), вихваляє велич Вітовта («Летописи Белорусско-Литовские», 1980. С. 59).

Відносини Вітовта 3 татарами вписувалися у його широке політичне бачення своєї ролі у Східній Європі, про що можна пересвідчитися, зокрема, $з$ його листування 1425 р. із Паулем фон Русдорфом, 29-м великим магістром ордену Тевтонських лицарів 3 1422-го до 1441-го року. Там згадується про те, що один із татарських ханів у той момент жив у Вітовта. Вітовт і наступні великі князі Литовські регулярно втручалися в кримську політику і мали мережу своїх агентів у Кафі, таких як вірменин Ованес (його безпосереднє залучення до кримської політики зафіксовано в багатьох документах) (Codex epistolaris Vitoldi Magni... 1882. P. 660 (no. 1159), 721 (doc. 1223)). Наступний великий князь Свидригайло - зробив те саме, що засвідчує його листування 3 великим магістром ордену Тевтонських лицарів (Liv-, Est und Kurlandisches Urkundenbuch, 1884. Vol. 8, XXXVII. S. 366, No. 624), а також його листи до короля Польщі (Halecki O., Z Jana Zamoyskiego Inwentarza Archivum Koronnego..., 1919. Vol. 12. Cz. 1. S. 198-199, 216).

Уся інформація із західноєвропейських, польських, литовських та інших джерел підтверджує один факт: кримські татари Солхата в Криму були частиною відцентрового процесу розпаду Золотої Орди. Деякі вчені вважають, що Хаджі Герай Хан оголосив себе незалежним ханом Криму в 1428 р. Це було ознаменовано появою кафинських монет (аспр) із генуезьким замком на лицьовому боці й тамґою клану Гераїв на зворотному. Їх поширення після 1433 р. $€$ непрямим свідченням того, що розпад Золотої Орди та відмежування Криму фактично відбувалися вже в цей момент. Ці аспри карбувалися в монетному дворі Кафи до 1453 р. Фактично об'єднані символи мегаполісу (castello genovese) 3 латинською легендою і татарською тамгою $з$ легендою арабською мовою можна розглядати як візуальне вираження подвійного підпорядкування (Фомичев Н., 1981. С. 225, 239; Еманов А., 1995. С. 111; Опимах О., 2005. С. 527; Козубовский Г., 2005. С. 156). Проте перші монети Хаджі Герай Хана датуються лише 1441 р. (тоді він почав вести справи і влаштувався в Саладжікі, між Чуфут-Кале i сучасним Бахчисараєм). Остання дата точніша; хоча раніше кримські татари були практично незалежними, а правління Хаджі Герая не могло початися в 1420 -х роках.

Унезалежнення кримськотатарської еліти було поступовим. Татари Солхата стали автономнішими під час династичних війн чотирнадцятого століття. Крім того, з 1400 до 1440 року протистояння між різними претендентами спочатку були підтримані Вітовтом, а пізніше й іншими руськими і литовськими князями, які не хотіли мати сильну Золоту Орду у своїй місцевості, але цінували військову допомогу незначних татарських правителів під час власних війн. Нарешті, в 1429-1431 рр. географічне ядро Золотої Орди вразила величезна посуха і чума: «В землях Сарая та в Куманії (Половецьке поле, або 
Дешт-і-Кипчак) виникла сильна посуха та надзвичайно велика чума, внаслідок чого загинула неймовірна кількість людей, бо лише деякі з них вижили зі своїми стадами» (Тизенгаузен В., 1884. С. 442). Золота Орда не могла існувати як панівний політичний гравець у Східній Європі. Її розпад $\mathrm{i}$, зокрема, утворення незалежного Кримського ханства стало питанням часу, незалежно від того, відбулося це в 1428 чи 1441 році.

Попри те, що в 1440-х роках Саїд-Ахмад I панував у степах, він мав погані взаємини з Польським королівством і з Великим князівством Литовським. Як-от, в 1444 р. він здійснив похід на Литву, в 1447 р. - знову на Поділля (Spuler B., 1943. С. 166), в 1447, 1449 та 1450 роках — на різні польські й литовські території (Греков И., 1963. C. 124), а в 1451 р. напав на Москву. При цьому в 1449 р. Саїд-Ахмад допоміг князю Михайлу Сигізмундовичу (1380-ті — 1451/52) зайняти Київ. Тому не дивно, що коли Хаджі Герай, який довгий час жив у Литві, проголосив себе незалежним кримським ханом, Казимир IV (тоді великий князь литовський, а з 1447 р. також король Польщі) підтримав і визнав його, оскільки йому був потрібен союзник проти Саїд-Ахмада I. Задовго до цього Крим був самодостатнім, більше не пов'язаний $з$ руйнівною Золотою Ордою, зникли старі шляхи торгівлі у Східній Європі, а нові не перетнули степи навколо Волги. Таким чином, Хаджі Герай міг насолоджуватися повною незалежністю, а його наступники на кримському престолі - широкою автономією під османським сюзеренітетом.

Генуезці Кафи в Криму були одними з гравців на цьому полі. У п’ятнадцятому сторіччі генуезькі колонії на Чорному морі вже не були сумирними прохачами, які торгували через пару прибережних торговельних пунктів, прохачами, чия торгівля та доля залежали від доброзичливості татар. Кафа стала великим і незалежним політичним актором. Попри ії вплив на місцеву політику, вона залишалася досить вразливою і все ще формально залежною від татар. У п’ятнадцятому столітті генуезці зрозуміли неминучість значних політичних змін у Чорноморському регіоні та намагалися зміцнити свої позиції, прямо утверджуючи своє панування або створюючи нові альянси (Близнюк С., 1998. С. 132). Татарський внутрішній розбрат був проблемою для кафіотів тільки в тому сенсі, що старі маршрути від Східної Європи до Центральної Азії залишалися небезпечними. Проте для генуезців з'явилася ще одна загроза, а саме великий князь литовський Вітовт, який бажав, аби Кафа визнала його сюзеренітет над генуезькими чорноморськими колоніями. Консули відряджали у Вільно посланців із подарунками, щоб умилостивити його. Один посланець, Баттіста Джентіле, пообіцяв Вітовтові підняти його прапори та герб у Кафі; проте, імовірно, не зробив цього, оскільки відверто перевищив свої повноваження (Мыц В., 2000. С. 331). Другого посланця, Даріо Грілло, пограбували дорогою до Литви татари (ab imperatore tartarorum); він втратив свої товари, коней і гроші в розмірі 300 сомо (2400 генуезьких лібр) (Archivio di Stato di Genova, Archivio Segreto (далі - ASG, AS), 3034, Diversorum, Filze 14, No. 2 / 6; публ.: Карпов C., 1998 С. 36). Таким чином, поводження з цим далеким, але все ще грізним литовським принцем було однією з проблем генуезців.

Князівство Феодоро, назване так на честь свого покровителя Святого Феодора ('Аүıь $\Theta \varepsilon o ́ \delta \omega \rho о \varsigma), \quad$ було грекомовною державою в передгір'ях Криму зі столицею в Мангупі. 3 чотирнадцятого століття воно стояло поперек горлянки кафіотам. Теодорити ворогували з генуезцями з приводу доступу до берегів і маршрутів, що перетинали гавані південно-західного Криму. Більше, область генуезького капітанства Готія (так називалось кримське узбережжя від Чембало до Лусти; грецькою - ПараӨа入аббıа, букв. «морський берег») здебільшого населяли грецькомовні православні люди, які прагнули повстати проти своїх латинських володарів. Князі Феодоро скористалися цим і намагалися максимально обмежувати генуезьку владу в Криму або за допомогою підбурювання місцевого населення до повстання, або шляхом безпосереднього вторгнення до генуезьких земель. Таким чином, у 1423 р. князь Алексіос напав на Лусту і Чембало, а генуезцям довелося витратити до 10000 сомо на захист міст. Панівна династія Феодоро (Габри або Габраси) була пов'язана з імператорською династією Трапезунда (Велики Комніни), яка спочатку контролювала частину колишніх візантійських володінь у Криму. Однак відносини двох грецьких держав не завжди були ідеальними, і це надавало генуезцям простір для маневру. У 1429 р. вони організували державний переворот у Трапезунді, а трон перейшов від Алексіоса IV до сина Іоанна (Chalkokondyles L., ed. J. Darko, 1927. P. 219-220; Laurent V., 1955. Р. 141-142). Водночас венеційці встановили відносини з князем Феодоро, головним ворогом Кафи і тому природним союзником для Республіки Святого Марка. Масштаб загрози князівства можна побачити з суми, призначеної генуезьким урядом для боротьби з ним (наприклад, 10 тисяч сомо у 1422 р.) (Archivio di Stato di Genova, San Giorgio, Sala 34, 590 / 1230, Massaria Caffae 1422, f. 209v).

1430-ті роки були часом латентного протистояння генуезців і венеційців на Чорному морі 3 деякими іскорками взаємної ворожості. Венеційці опинилися у важкому становищі вони почали нову антигенуезьку війну в 1431 р. (Dupuigrenet Desroussilles F., 1979. P. 111-122), тоді як один із двох їхніх оплотів у Чорному морі, Тана, в 1431 р. був під загрозою зникнення через 
татарську облогу (Doumerc B., 1988. Р. 365-366; Карпов С., 2009. С. 166). Це тимчасово примирило генуезьке і венеційське населення проти спільного ворога (Dupuigrenet Desroussilles F., 1979. Р. 116; Мыц В., 2000. С. 33; це свідчить про те, що в контексті складної міжнародної ситуації як в Італії, так і в Чорному морі населення італійських колоній не завжди відповідало орієнтації свого мегаполісу), як і чума, від якої помер венеційський консул Вітторіо Долфіно (Талызина А., 1998. С. 174), що змусила віцеконсула просити кафіотів про допомогу (Dupuigrenet Desroussilles F., 1979. Р. 115). Проте кафіоти хотіли напасти саме на венеційську Тану, що могло б статися, якби вітер із півночі не блокував їхній вихід iз гавані Кафи. Венеційський сенат був поінформований про цю зраду байлом Константинополя та владою Негропонту (Евбея) (Талызина А., 1998. С. 174). 5 липня 1431 р. він погодився відправити до Тани тридцять арбалетників, а за п’ять днів додав 2000 дукатів (Archivio di Stato di Venezia (далі - ASV), Senato, Misti, reg. 58, f. 65r-v, 69r-v), щоб захистити місто від генуезців і татар. Ця експедиція на чолі з Андреа Лоредано відійшла на початку серпня, маючи вказівки з'ясувати наміри кафіотів i, якщо вони будуть ворожі, напасти на Кафу й будь-який генуезький корабель на своєму шляху. Проте дві галери флоту Лоредано зазнали корабельної аварії біля узбережжя Генуезької Газарії і сіли на мілину біля мису Меганом, де ї миттєво помітили генуезці з Солдаї (Карпов С., 1995; Талызина А., 1999. С. 65). Причина криється в тому, що венеційці не знали місцевого морського шляху і пересувалися занадто близько до берега, коли обходили мис. Кораблі були зруйновані прихованим підводним кам'янистим хребтом, що розташовувася приблизно за 200-300 м від видимого узбережжя Меганому і був особливо небезпечний для кораблів під час штормів. Венеційці не першими зробили цю помилку, оскільки археологи виявили сліди численних корабельних аварій різних епох у цій ділянці. Ще одна помилка полягала в тому, що вони сіла на мілину на безлісному мисі Меганом, а тому були дуже помітними.

8 жовтня 1431 р. Колардо де Палаваніа, консул Солдаї, проінформував про цей інцидент Франческо Ломелліні, консула Кафи, у той же час зібравши усі вцілілі товари та ув'язнивши полонених венеційців. Ломелліні порадився із міськими старійшинами (anziani) і вирішив відправити до Солдаї Джованні Спінолу і Доменіко деі Франкі ді Маньєрі для інвентаризації товарів. Новий консул Солдаї Антоніо ді Монтальдо, який щойно приїхав та обійняв цю посаду, провів інвентаризацію разом із мешканцями Кафи, оцінивши здобич у 900 срібних сомо Кафи. Було вирішено витратити їх на захист генуезьких міст, що було досить своєчасним, оскільки Лоредано почав атакувати лігурійців, захопивши кілька генуезьких галер 24 грудня 1431 p. (ASG, AS, 3037, Diversorum, Filze 17, No. 24; публ.: Карпов С., 1998. С. 44).

У 1432 р. нова венеційська muda (караван галер), що приїжджала до Тани на чолі зі Стефано Контаріні, загрожувала кафіотам. Ця muda, переправляючи 2000 дукатів на витрати на оборону в Тані, повинна була домогтися звільнення полонених, атакувати генуезькі кораблі та переконатись, що князь Феодоро Алексіос залишався вірним союзником Венеції і все ще мав намір виконати перед нею деякі свої зобов'язання (...tam pro faciendo viagium suum bono tempore, quam pro succurrendo loco Tane et pro executione rerum, quas dominus Alexius, dominus Gothie, intendit facere dominio nostro) (ASV, Senato, Misti, reg. 58, f. 133r-v, cp.: ASV, Senato, Misti, LV, f. 5 [6] v; ASV, Senato, Misti, LV, f. 36 [37] v); Sathas K., 1882. P.193-197; Jorga N., 1899. P. 554; Régestes des délibérations..., 1961, No. 2282. Cp.: Vasiliu V., 1929. C. 310). Контаріні не вдалося звільнити полонених венеційців, хоча він з'ясував, що з ними гуманно поводяться в Кафі, дозволяють покинути в'язницю і відвідувати месу (ASV, Senato, Misti, LVIII, f. [203r], 207r. Régestes des délibérations..., 1961. No. 2311, 2319). Немає сумнівів у тому, що ці зобов'язання прирівнювалися до антигенуезьких дій. Венеційці постійно повідомляли Алексіосу про події в Італії, де йшла війна між двома морськими торговельними республіками. Схоже, що він почав готуватися до наступу на генуезькі колонії у Криму заздалегідь, збираючи всі грецькі сили, які не хотіли залишатися під владою кафіотів, насамперед місцевого православного населення Чембало, готуючи їх до повстання, яке відбулося зимою 1433 р. (ASLSP 6, 1868. P. 810; Vasiliu V., 1929. Р. 311; Чиперис A., 1961. С. 291-307; Мыц В., 2000. С. 336-337). Вибір пори року для цього повстання був цілком зрозумілий, оскільки зима - найгірший час для навігації у Чорному морі, а тому Генуя не могла відправити флот для допомоги своїм колоніям у надзвичайних ситуаціях. Алексіос створив формальне виправдання для участі князівства Феодоро в повстанні, надіславши лист консулу Кафи Батісті ді Форнарі, вимагаючи поступитися

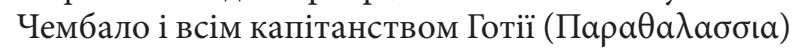
(Колли Л., 1913. С. 99-139).

Повстання місцевих жителів проти латинського панування не були рідкісними ще до 1433 р. Неприязне ставлення місцевого населення до італійців легко посилювалось. У той же час можна сміливо сказати, що жоден інший бунт не був таким успішним і не завдав генуезцям стільки неприємностей та втрат, як цей. Повстання почалося наприкінці лютого 1433 р., коли жителі Кафи відмовились підпорядковуватись генуезькій адміністрації. Можливо, в Чембало на той момент не було консула, на користь повстанців (Мыц В., 2000. С. 340). На допомогу останнім прийшов князь Алексіос, аби захопити Чембало. Трохи 
пізніше він також розграбував генуезький корабель, завантажений галунами (Карпов С., 1990. С. 139). Можливо, Алексіос також окупував капітанство Готії, що не мало викликати складнощів, оскільки на цих територіях було лише невелике населення генуезців і невеликі гарнізони в замках. 3 генуезьких джерел, однак, ми знаємо лише те, що колонізатори втратили Чембало, і не можемо бути впевненими, означає це цитадель або всю територію консульства (як адміністративна частина Готія перебувала під юрисдикцією консула Чембало). Отже, це просто гіпотеза, для доведення якої потрібно поглиблене дослідження проблеми (Бертье-Делагард А., 1920. С. 65; Мыц В., 2000. С. 337-338). Так чи не так, Алексіос став серйозною загрозою, тому що, володіючи Чембало, він міг загрожувати Кафі й створювати перешкоди для торгівлі генуезцями, не кажучи вже про верфі Чембало, які були життєво важливі для кафіотів і які могли б використовуватися проти них теодоритами.

Новина про повстання досягла Генуї лише влітку 1433 р. У листі від 16 липня від генуезців до герцога Мілана йдеться про втрату Чембало (Alexio de lo Tedoro tempore noctis, cerca finem mensis februari proxime excti... oppidum preciosum hujus civitatis in orientalibus portibus situm, Cimbalum vocatum) (Jorga N., 1899. P. 558-559), те ж саме бачимо і в генуезьких хроніках (Georgii et Johannis Stellae Annales..., 1730: 1311-1312; Giustiniani A., 1537. P. 191-192; Folieta U., 1704. Р. 567; Agosto А., 1977. Р. 513-517). Влада Генуї відреагувала, хоч і не дуже швидко. У жовтні 1433 р. дворянина Карло Ломелліно призначили головою флоту, відправленого до Чембало, щоб відвоювати його, придушити повстання і відновити правопорядок (Agosto A., 1981. Р. 103-108; Andreescu S., 2006. Р. 259-272). Перша згадка про Карло Ломелліно в джерелах датується 1427 р., коли він отримав від Філіпо Марія Вісконті (13921447) цитадель і бург Вентімільї як заставу на десять років в обмін на 3000 дукатів, що він позичив цьому князю, тодішньому володареві Генуї (Agosto A., 1977. Р. 513). Через наближенням зими генуезці не відправили експедицію Ломелліно негайно, обмежуючи свій гнів на звинувачення Алексіоса (... rebellum Alexium de Theodoro, qui tum per magnificum comune Janue sive eius officiales in Caffa de stercore [sic] fuerit erectus, asumpto thementatis spiritu Cimbalum oppidam) (Мыц В., 2000. C. 341).

У березні 1434 р. флот Ломеліно, що складався 3 двадцяти суден (дев'ятнадцяти галер та одного фуста) 3 6000-ми осіб, залишив гавань Генуї i набрав додаткових найманців та fusta з острова Хiоc, після чого попрямував до Чорного моря, увійшовши в нього до 31 травня 1434 р. (Agosto A., 1981. Р. 103-108). До 4 червня флот прибув до Чембало, але виявив, що вхід у гавань перекритий ланцюгом. Наступного дня нападники встигли знищити ланцюг, після чого галери увійшли в гавань. Далі почалася облога із землі з використанням гармат. 8 червня генуезці здійснили остаточний штурм і взяли фортецю Святого Георгія (бург), а потім фортецю Святого Миколая (цитадель). Це призвело до розграбування та різанини. Переможці вбили усіх захисників, окрім Олобея (тюркського «великого князя»), сина князя Алексіоса, який командував гарнізоном, а також якогось грека з Кандії (про цю людину див.: Agosto A., 1977. Р. 515). 9 червня генуезькі галери висадили війська біля Каламіти, головного порту теодоритів, і після компромісу погодилися зберегти мешканцям життя і майно, якщо вони складуть зброю. Проте наступного дня, коли прибули додаткові війська, виявилося, що місто було порожнім, а міщани-втікачі забрали з собою усе своє майно. Генуезьке військо спалило місто, навіть не замислюючись про напад на могутню фортецю Мангуп, і тому здавалося, що остаточного успіху у війні з Феодоро досягнуто.

Проте генуезці не думали, що їхня місія закінчилась. Замість того, щоб повернути армію до Генуї, влада Кафи спрямувала їі проти татар. Спочатку вони вдалися до дипломатичних засобів; але після того, як татари вбили посланця кафіотів, було вирішено відправити Ломеліно проти Солхата. Ця кампанія розпочалася 22 червня 1434 р. Генуезька армія з прапорами Карло Ломеліно, Комуни Генуї та герцога Мілана складалася з 8000 осіб і простягалась на дві милі завдовжки. Рухалася вона повільно, а тому була дуже вразливою. Зрештою армія досягла місця під назвою Кастадзона (Castadzona), де планувалося відпочити і вдягти зброю, але раптом з'явилися татари, спочатку кілька, а потім близько 5000. Вони почали обстрілювати неозброєних італійців зі своїх луків. Сталася паніка, і генуезькі воїни намагалися відступити у безладі, але татари переслідували їх. Більша частина італійської армії була знищена, і лише деякі з них втекли до Чембало. Наступного дня татари обезголовили всі тіла і зробили з тих голів дві піраміди (Мыц В., 2000. С. 330-359; Мыц В., 2009. С. 153-179). Це була нищівна поразка генуезьких сил. Більше того, як відомо з листа, надісланого венеційським байлом Константинополя Алексіосу через Монкастро, датованого приблизно 1436 р. або трохи пізніше, теодорити повернули Каламіту й оселилися там (Байер Х.-Ф., 2001. С. 212; Małowist M., 1947. P. 43). Інший бунт у Чембало, напевно, викликаний венеційцями і теодоритами (Близнюк С., 1998. С. 130), відбувся в 1439 р., можливо, через дефіцит хліба. Консул Чембало був поранений, і ще раз генуезький уряд мав ужити екстремальних заходів, відрядивши нову експедицію на чолі 3 Томмазо Кампофрегозо (Карпов С., 1995. С. 16). Консул, масарій та рада Кафи відправили Антоніо 
Піно, який залишався консулом одинадцять місяців та шість днів і зумів заспокоїти бунтівне місто. Його замінив burgensis Кафи Джироламо д’Аллегро, призначений на цю посаду в Генуї.

Хоча генуезці зазнали в 1434 р. гіркої поразки, правитель Солхат (мабуть, Хаджі Герай) не зміг повною мірою скористатися своєю перемогою і мав відступити в тому ж році до свого покровителя Сигізмунда Кейстутовича в Литву через наближення військ Саїд-Ахмада I (Мыц В., 2000. С. 351). Венеційці не отримали великої користі від тимчасової генуезької слабкості. Крім того, Республіка Святого Марка зазнавала постійних труднощів, відправивши в Тану галеї з muda i фінансувавши укріплення та гарнізон, і ці проблеми з часом лише загострювалися. Тобто, 13 квітня 1434 р. Венеційський сенат ухвалив зобов'язати байло Константинополя заплатити 2000 дукатів для захисту Тани (ASV, Senato, Misti, reg. 59, f. 42v, 52r - 53v; цей наказ був повторений в 1437 p. (Ibid., reg. 60, f. 8r-v)), і венеційці знову зіткнулися 3 проблемою витрачання великих коштів на гарнізон в 1435 р. (ASV, Senato, Misti, reg. 59, f. 112r-v). У 1435 р. венеційці встановили відносини 3 молдовськими лідерами (Régestes des délibérations..., 1961. No. 2381, Apr. 19, 1435). У 1435 р. у Кафі вирувала чума - і населення втекло до Тани, Монкастро й інших міст (Карпов С., 1995. С. 15-16). У 1436 р. Венеційський сенат наказав галерам mudae відразу ж відплисти в Тану під загрозою штрафу в 500 дукатів за кожного неслухняного (Карпов С., 1994. С. 58; див. також ASV, Senato, Misti, reg. 59, ff. 158r - 159v). Проте в 1436 р. галери Тани відклали свій від'ізд, що змусило сенат вжити додаткових заходів і стимулів для відновлення плавання (ASV, Senato, Misti, reg. 59, f. 164r-v, 166v). Б. Думер вважав часті затримки галер до восьми тижнів симптомом структурної кризи Венеційського торговельного флоту (Doumerc B., 1985. Р. 605-623; див. також Stöckly D., 1995). У 1437 р. сенат був поінформований про чуму на Чорному морі й запровадив період ізоляції для галер, які йшли з Константинополя і Трапезунда (однак імператор

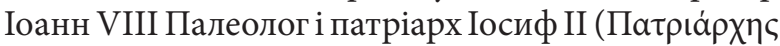
$\mathrm{I} \omega \sigma \eta \dot{\varphi} \mathrm{B} ;$ ? - 1439) прибули до собору у Феррарі на тих же галерах, що поверталися до Венеції з Тани) (Nicol D., 1988. P. 375). У 1438 р. галери Тани знов не вийшли в море (Карпов С., 1994. С. 58). В указі сенату від 28 березня 1439 р. зазначається, що новообраний консул Тани був змушений залишитися в Кафі, бо галери не могли досягти венеційського форпосту; тому було вирішено виділити йому половину належної платні за перебування в Kaфi (ASV, Senato, Misti, reg. 60, f. 133v). Ситуація, коли новий консул не міг досягти Тани, була узвичаєною: наприклад, Арсеніо Дуодо, Йосафат Барбаро і Нікколо де Варсис були змушені залишитися в Константинополі взимку 1436 р.
Політичні зміни в Італії та Генуї не заважали Кафі. Суверенітет герцога Мілана над Генуєю, що тривав 3 1421-го до 1435-го року, закінчився в 1436 р. (de Negri T., 2003. C. 549-558), гарантом їі незалежності були Венеція та Флоренція, а також був обраний новий дож Томмазо Кампофрегозо (1436-1442). Слід зазначити, що протягом майже ста років існування колоніальної імперії в Газарії Генуя втрачала свій суверенітет п’ять разів: 1) французьке правління в 1396-1409 рр.; 2) правління Теодоро II, маркіза Монферрата, в 14091413 рр.; 3) міланське панування Філіпо Марія Вісконті 1421-1435 (правління гібеллінів); 4) правління Франції в 1458-1461 рр.; 5) міланське панування Франческо I Сфорци в 1464-1478 рр. Проте адміністрація колоній Газарії фактично працювала так само як до, так і після цього. Водночас, з погляду відносин Заходу з Візантією, порядок денний в 1430-х роках був питанням об'єднання Церкви. Це дало змогу Заходу організувати ідеологічно обгрунтований антиосманський хрестовий похід і продовжити життя Константинополя. Розраховуючи на допомогу від західних держав, імператор Іоанн VIII Палеолог і патріарх Іосиф II Константинопольський спочатку два роки зупинялися у Феррарі (потім - у Флоренції), щоб домовитися про більшість умов, встановлених папою Євгенієм IV, та підписали 6 липня 1439 р. цей союз. Союз був остаточно відхилений більшістю православної ієрархії, духовенства та населення, але став початком хрестового походу проти мусульманської експансії. Проте, незважаючи на героїчні зусилля Яноша Гуньяді (1387-1456), який переміг османів у 1443 р., й на те, що Георг Кастріоті Скандербег (1405-1468) у той же рік підняв антизахідний бунт в Албанії, європейські монархи не дуже захопилися ідеєю хрестового походу (про ідеологічний дискурс під час хрестових походів дивіться: Hankins J., 1995). Дійсно, повстання Георгія Кастріоті Скандербега було найуспішнішим антиосманським заходом того часу. Скандербег виріс і був вихований в ісламі, але відкинув іслам і прийняв християнство. Почавши повстання в 1443 р., він був підтриманий місцевим дворянством, кілька разів переміг османів, об'єднався з королем Угорщини і змусив Мурада II відступити від Круї, де напав на нього. У 1444 р. Скандербег уклав договір із Венецією та князями Албанії, відомий як Ліга Лежі, і почав партизанську війну в Північній Албанії, фактично здолавши османів у 1449 і 1451 роках. Мехмед II Фатіх, або Завойовник (1432-1481), якого не можна сприймати за недієздатного воїна і політика, вважав за краще визнати Георгія Кастріоті Скандербега правителем Албанії.

Експедиція хрестоносців була врешті-решт відряджена, але це була остання велика спроба Заходу допомогти Візантії. Кампанія закінчилася катастрофою. У 1444 р. у Варненській битві 
армія хрестоносців на чолі з Владиславом III Варненчиком, королем польським та угорським (1424-1444), була повністю розгромлена османськими військами. Інша експедиція хрестоносців iз Бургундії, відправлена герцогом Філіпом III під командуванням Валеріана де Вавріна, вступила в Чорне море в 1445 р. для участі в новій антиосманській експедиції, але також не змогла досягти своєї мети: замість хрестового походу проти мусульман вони почали грабувати береги Чорного моря, завдаючи більшої шкоди грекам і генуезцям, аніж османам. Янош Гуньяді зазнав поразки у 1448 р. у Другій битві під Косово; він не зміг врятувати князівство Морея, але, можливо, зберіг незалежність Албанії під Скандербегом. Після цього світ латинського християнства не здійснює жодних серйозних спільних спроб протистояти османській загрозі.

Оскільки розширення Османської імперії ставало все небезпечнішим для країн чорноморського регіону, до середини п'ятнадцятого століття більшість із них, зокрема їхні найзапекліші вороги, взагалі припинили використання військової сили у своїх внутрішніх конфліктах, віддаючи перевагу дипломатичним інструментам. Наприклад, відносини між генуезцями й імператором Трапезунда ставали все гіршими. Зрештою, у 1446 р. Іоанн IV Великий Комнин відправив флот під командуванням свого брата деспота Давида проти Кафи. Ця експедиція стала серйозною загрозою для міста, оскільки флот складався з тринадцяти галер, а дії Іоанна IV підтримали Хаджі Герай Хан, князь Феодоро (який дозволив Давиду використовувати гавань Каламіти в Криму, резиденції спадкоємця князівства) і правителі Сінопи і Кастамону. Однак це все не призвело до війни, оскільки Кафа заплатила за запаси продуктів і подарувала 1413 аспрів Давидові (Мыц В., 2000. С. 358-359). Це було мудре рішення, оскільки пізніше, в 1447 р., османи напали на Трапезунд і вперше вдерлися до Криму (Байер Х.-Ф., 2001, С. 216), змусивши імператора та генуезців укласти договір.

У квітні 1453 р. османська армія на чолі з Мехмедом II розпочала облогу Константинополя. Генуезці, венеційці й каталонці брали участь в обороні, але їхні сили були занадто малими. Командувач генуезцями Джованні Джустініані Лонго взяв із собою лише 700 солдатів; у генуезців і венеційців було тільки по п’ять кораблів у кожній групі відповідно і низка солдатів на міських стінах (Георгий Сфрандзи, 1953. С. 417). Зрештою після кількох нападів Константинополь впав 29 травня 1453 р. Після цих трагічних подій і до падіння Кафи в 1475 р. проблеми, що хвилюють східних латинів, були такими: «Неможливо було дістатися до Чорного моря через бомбардування Румеліхісар; султан вимагав все більше податків в обмін на не завжди безпечний мир; турецький флот періодично з'являвся як ознака нестабільної політичної ситуації; вони закликали на допомогу західні країни, намагаючись уникнути трагедії, яка тоді здавалася неминучою» (Olgiati G., 1991. Р. 382-383).

Кафіоти мали відправити своїх посланців до Мехмеда II заради власної безпеки (Vigna A., 1868. Р. 297-301. Babinger F., 1957. Р. 110). Однак ці запобіжні заходи не врятували генуезців від втрати Самастро безпосередньо після завоювання Константинополя. Завоювання Криму не було частиною найближчих планів султана; він лише зобов'язав кафіотів сплачувати щорічний податок, що ті й робили без особливої допомоги від лігурійської метрополії. Спочатку цей податок складав близько 2000 дукатів, потім його було збільшено до 3000, а далі - до 4000 дукатів. Під час нечисленних військових зіткнень кораблів Османської імперії з латинськими в період між 1453-м і 1475-м роками мусульмани зазнавали поразок, навіть незважаючи на їхню чисельну перевагу. Проте проходження через протоки насправді не було безпечним для генуезців.

Після падіння Константинополя Румеліхісар була майже непереборною перешкодою для генуезців, які, на відміну від венеційців, не отримали жодного договору від султана, що міг забезпечити принаймні теоретично безкоштовний прохід через протоку. Виживання колоній Генуезької республіки, навіть найвіддаленіших, які були останнім виживанням християнства, тепер цілком залежали від турок і татар, і було дійсно нестабільним та драматичним. Протягом останніх двадцяти років виживання Кафи та інших генуезьких територій Чорного моря залежало від капітанів флотів Банку Сан Джорджіо та купців, які іноді ціною власного життя намагалися продертися крізь велике турецьке блокування (Olgiati G., 1991. Р. 383-387).

3 одного боку, Генуя не мала (крім Александрії, де в торгівлі непохитно переважали венеційці) жодного доступу до ринків Персії та Індії, крім Кафи, Трапезунда (de la Primaudaie É., 1848. Р. 190) і частково Бурси. 3 другого, після 1453 р. регулярно плавати до Чорного моря через Константинополь стало важче. Дипломати припинили користуватися маршрутом через протоку до $1470-$ - років. У 1473 р. Катаріно Дзено рушив з Сухумі через Кафу до Польщі (Tardy L., 1971. P. 48) й Амброджіо Контаріні, венеційський дипломат і торговець, відправлений до татарського хана, вперше вирушив до Польщі, потім до Києва, а звідти до Кафи (Tardy L., 1971. P. 58).

Після падіння Константинополя в 14541455 рр. у місті спалахнула чума. Папи Микола V (1447-1455) і Каллікт III (1455-1458) марно закликали до хрестового походу проти османів. Доступ із метрополії до колоній майже повністю звільнений від султана Османської імперії. Іноді генуезці використовували маршрут Дунаєм, але 
це не могло замінити втрату протоки (Колли Л., 1911. С. 2). 15 листопада 1453 р. Генуезький сенат передав усі чорноморські колонії Комуни в Банк Сент-Джордж, який тоді управляв Генуезькою Газарією до кінця іiі існування. Перші кроки були відносно успішними: таким чином, в 1454 р. Кафа протистояла нападу спільної татарської армії (Волков М., 1872. С. 110-114). Проте більшість дворян, обраних консулами протекторами Банку святого Георгія, відмовилися вирушити до Газарії. Центральна адміністрація не контролювала деякі частини колоній i часто не мала можливості гарантувати правопорядок. Таким чином, генуезький замок Батіаріо (Базіар) на береговій лінії Азовського моря, що належав з 1457 р. Іларіоне Мартіні, був захоплений за його відсутності лідером-найманцем (condottiero d'una compagnia di ventura) Джованні Бозіо (Giovanni Bozio), якому власник довірив охороняти замок. У той час, як Іларіоне Мартіні було надано Комуною дві компанії стипендіатів Кафи під командуванням Якопо ді Капуа та Антоніо Джентіле, щоб повернути собі майно, одна з галер повстала і відпливла до Трапезунду. Замок, проте, нарешті отримав законного власника (Колли Л., 1905. С. 14; Волков М., 1872. С. 128). (Про місце розташування замка див: Брун Ф., 1872. С. 293.) Той факт, що Мартіні придбав цей замок ще в 1457 р., вже після падіння Константинополя, свідчить про те, що попри всі проблеми генуезці зацікавилися Газарією та вклали великі інвестиції, зокрема купили землі.

У контексті османської експансії генуезці в Криму повинні були мати мирні стосунки з місцевими правителями ханства. У 1455-1457 pp. у Кримському ханстві відбулася війна, а генуезці підтримували свого союзника Хаджі Герая, що зміцнило зв'язки між Кафою і ханом, тоді як Генуезька Газарія і Кримське ханство перейшли під сюзеренітет Казимира IV Ягеллончика (великого князя литовського в 1440-1492 рр., короля Польщі в 1447-1493 рр.). Хаджі Герай, який, очевидно, терпів генуезців або, можливо, навіть віддавав перевагу їм, помер у 1466 р. - i розпочалася війна за правонаступництво (Колли Л., 1918. С. 130-131). Другий син Хаджі Герая Нур-Девлет Герай кілька разів перемагав лише на короткі періоди в 1466-1467 рр., потім - в 1467-1469 pр. і в 1475-1476 pр., але був переможений у 1478 р. Спочатку він жив як заручник у Кафі, потім після спроби його вбивства був переведений до Солдаї і нарешті залишив Крим, ставши васалом Московського Іоанна III, прийнявши князівство Касимова від нього в 1486 р. Його противник Менглі I Герай (1445-515), шостий син Хаджі Герая, був підтриманий генуезцями у своїх претензіях на кримський престол (Волков М., 1872. С. 143), i тому його правління було набагато сприятливішим для Кафи. Насправді частина охоронців
Менглі I Герая у його цитаделі Кирк-Ор (сучасне місто Чуфут-Кале) складалася 3 socii (військовослужбовців) Кафи. Хоча ситуація ставала все нестабільнішою і не було великих повстань, як у 1433 р., однак інструкції співробітникам генуезької Газарії вказують на часті сплески насильства та пограбування (Cazacu M., Kevonian K., 1976. Р. 495-496).

До 1470-х років генуезькі й венеційські колонії були приречені. Останній рік генуезького і венеційського панування майже у всіх них становив 1475, тобто раніше, ніж Монкастро і Лікостомо, які впали лише в 1484 р., після того як османська армія перетнула Дунай і напала на них. Після 1484 р. правління генуезців та венеційців у регіоні закінчується і Османська імперія починає керувати всім районом Чорного моря (про останні місяці та дні Кафи дивіться: Колли Л., 1911. С. 1-24; Там само, 1918. С. 129-171; Там само, 1913. С. 99-139; Там само, 1905. С. 1-28). Влада Кафи необережно втручалася в призначення нового татарського тудуна, що викликало невдоволення деяких татар і врешті-решт призвело до їхнього заклику до вторгнення.

Конфлікт між союзом Кафи і Менглі Герай Ханом, з одного боку, і тудуна Емінеха, який напав на Кафу, з другого, став чудовим приводом для втручання Мехмеда II, тому що, попри союз між Менглі Гераєм і генуезцями, кримськотатарське дворянство не було в захваті від присутності генуезців і було готове з радістю позбутися їх. Як тільки Мехмеда II поінформували про це протистояння (i, можливо, він отримав від кримських татар таємне запрошення втрутитися), він відклав військову кампанію до Егейського архіпелагу, заплановану на 1475 р., уклав мир із Венецією і відправив військо на чолі з Гедік Ахмет Пашою до Кафи, де воно висадилося 31 травня 1475 р. (Колли Л., 1911. С. 2-4). Ні Казимир IV, король Польщі та великий князь литовський, ні Владислав II, король Богемії, який також був ворогом османів, не змогли відправити свої війська, щоб допомогти Кафі. Імовірно, Владислав II хотів би це зробити, але був пов'язаний договором із Венецією, яка в цей момент була в конфронтації з Генуєю. Після семиденного нападу Кафа здалася османам 1 червня 1475 р. (деякі джерела як західного, так і східного походження під час падіння Кафи доступні в: Cazacu M., Kevonian K., 1976; наприклад, лист перською мовою: Ibid., с. 506-511; та деякі вірменські джерела), а інші генуезькі колонії були захоплені в наступні місяці.

Незабаром після італійських колоній армія Гедика Ахмета Паші захопила Менглі Герай Хана (він був, однак, відправлений до Криму за три роки, щоб керувати ханством, визнавши себе васалом султана) і завоювала останню державу, здатну чинити опір у Криму - Князівство Феодоро. Однією з причин цього завоювання були 
зв'язки між новим правителем Феодоро і ворогом османів - князем Молдови Штефаном III Великим, який був у Чорноморському регіоні єдиною реальною владою, здатною протистояти османам (Andreescu S., 1982. Р. 257). У тому ж 1475 р. він відправив до князівства Феодоро свого тестя Александра Габраса, щоб замінити тодішнього князя, брата Александра. Лист князя Штефана III від 20 червня 1475 р. свідчить про успіх Александра. Однак це також доводить усвідомлення Штефаном падіння Кафи. Гедік Ахмед Паша взяв Мангуп в облогу наприкінці року, й за п’ять місяців місто впало. (Про зв'язки Стефана III Великого та Князівства Феодоро див.: Bogdan I., 1913. Р. 324-328. Ті ж листи свідчать, що корабель з італійцями з Мангупа (sic) нещодавно прибув до Альби. Про сімейні зв'язки дивіться: Герцен А., 2004. С. 226-241. Степаненко В., 1990; Там само, 2001. С. 335-353.)

Грецькі джерела повідомляють, що після того, як війська Мехмеда II захопили Кафу, іiі мешканці були переселені до Константинополя (Ecthesis chronica..., 1902, 18.19-20; 33.15). Кілька інших грецьких літописів повістують про падіння Кафи (Chronographia brevis: 229 / 14; Chronica Byzantina breviora... Chronicle 38,2 section 17 line 1 (17); Ibid. Chronicle 58,1 section 18 line 2; Ibid. Chronicle 37,2 section 12 line 1 (12)). Про це свідчать і генуезькі джерела (Roccatagliata A., 1982. C. 7; Pistarino G., 1986. C. 75-76).

Основною причиною розгрому більшості держав Чорного моря османами, можливо, була недалекоглядність їхніх правителів. Політика протистояння османській загрозі ніколи не була послідовною ані серед західноєвропейських держав, насамперед Генуї та Венеції, ані серед місцевих християнських і мусульманських князів. Давня конкуренція між Генуєю та Венецією не була зведена до мінімуму через небезпеку втрати колоній Чорного моря. Оскільки Венеція мала лише торговельні станції в Трапезунді й Тані, основною метою іiї політики в Чорному морі було створення антигенуезької ліги. Таким чином, до XV ст. венеційцям вдалося залучити до деяких дій проти Генуї та їі колоній кілька держав:
Трапезундську імперію, Молдовське князівство, Велике князівство Литовське, Князівство Феодоро, а також кримських татар та інших. Через експлуатацію місцевого населення, культурні та релігійні бар'єри, а також інтриги Республіки Святого Марка генуезькі колонії на Чорному морі були здебільшого у ворожому оточенні та без союзників. Однак венеційці мали еквівалентного суперника, оскільки генуезці представляли, мабуть, найбільш прагматичну, хитру і цинічну силу в міжнародних відносинах. Тут слід зазначити, що і генуезці, і венеційці у своїй колоніальній політиці дотримувалися принципу divide et impera, спираючись на дипломатичну мережу союзників серед місцевих правителів і намагаючись обмежити проникнення одне в одного в цей регіон. Цей тип політики був згодом застосований до пізнішої колонізації.

Отже, здебільшого ранньомодерний доіндустріальний колоніалізм діяв реактивно. Побудова колоніальної імперії у формі, у якій вона формувалася пізніше, часто не була на думці в перших колоністів: сама імперія з'явилася як відповідь на тиск місцевих політичних діячів, які можуть поставити під загрозу комерційне проникнення. Це прямо стосувалося генуезького і венеційського колоніалізму. 3 одного боку, воно було спричинено низкою політичних та економічних проблем, і генуезці та венеційці навчилися користуватися місцевими протиріччями та нестабільністю, з другого, генуезці зобов'язані були формувати їхній територіальний домен у Криму в період 1360-1390 рр., а також здатність гнучко адаптуватися до мінливих умов торгівлі. Подальший розвиток і дозрівання колоніальної політики, ландшафту, адміністрації, структури міграції та торгівлі багато в чому визначалися викликами генуезькому колоніалізму. Ми можемо оцінити успіх цих перетворень і дозрівання, але не можемо заперечувати причинний зв'язок між тиском і зовнішніми та внутрішніми, політичними й економічними викликами, з одного боку, і розвитком колоніальної ситуації в Генуезькій Газарії, з другого.

\section{ДЖЕРЕЛА}

1. Байер Х.-Ф. История крымских готов как интерпретация Сказания Матфея о городе Феодоро. Екатеринбург, 2001. 498 с.

2. Бертье-Делагард А.Л. Исследование некоторых недоуменных вопросов средневековья в Тавриде. Известия Таврической ученой архивной комиссии. 1920. № 57. С. 1-135.

3. Близнюк С. Кошелек и жизнь генуэзцев в Константинополе и Адрианополе в середине XV в. Причерноморье в средние века. 1998. № 3. С. 126-144.

4. Брун Ф. Atlante idrografico del medio evo posseduto dal prof. Tammar-Luxoro, publicato a facsimile e annotalo dai socii C. Desimoni e L. Belgrano. Записки Одесского общества истории и древностей. 1872. № 8. C. 289-300. 
5. Волков М. Четыре года города Кафы (1453, 1454, 1455 и 1456). Записки Одесского общества истории и древностей. 1872. № 8. С. 109-144.

6. Георгий Сфрандзи. Большая хроника. Византийский временник. 1953. № 3.

7. Герцен А.Г. Молдавия и княжество Феодоро в 1475 г. Античная древность и средние века. 2004. № 35. С. 226-241.

8. Грамота Илиаша воеводы и господаря Молдавского Владиславу королю Польскому 1434 года, сентября. Записки Одесского общества истории и древностей. 1860. № 4. С. 323-330.

9. Греков И. Восточная Европа и упадок Золотой Орды (на рубеже XIV-XV вв.). М.: Наука, 1975. 519 с.

10. Греков И. Очерки по истории международных отношений Восточной Европы в XIV-XVI вв. M.: Издательство восточной литературы, 1963. 376 с.

11. Еманов А. Север и Юг в истории коммерции на материалах Кафы XIII-XV вв. Тюмень, 1995. 227 с.

12. Карпов С. Греки и латиняне в венецианской Тане (середина XIV - середина XV вв.). Причерноморье в средние века. 2009. № 7. С. 164-173.

13. Карпов С. Итальянские морские республики и Южное Причерноморье в XIII-XV веках: проблемы торговли. М., 1990. 336 с.

14. Карпов С. Причерноморье в XV веке по материалам собрания Diversorum, Filze секретного архива Генуи. Причерноморье в средние века. 1995. № 2. С. 9-19.

15. Карпов С. Путями средневековых мореходов. М., 1994. 158 с.

16. Карпов С. Регесты документов фонда Diversorum Filze секретного архива Генуи, относящиеся к истории Причерноморья. Причерноморье в средние века. 1998. № 3. С. 9-81.

17. Климанов Л. Крымские памятники средневековой генуэзской лапидарной эпиграфики: возможности источника. Сугдейский сборник. Вып. II. Киев-Судак, 2005. С. 454-484.

18. Козубовский Г.А. О времени появления кафинских надчеканок на джучидских монетах. Сугдейский сборник. Вып. ІІ. Киев-Судак, 2005. С. 155-160.

19. Колли Л. Исторические документы о падении Каффы. Известия Таврической ученой архивной комиссии. 1911. № 45. С. 1-24.

20. Колли Л. Каффа в период владения ею банком св. Георгия (1454-1475). Известия Таврической ученой архивной комиссии. 1911. № 47. С. 75-112.

21. Колли Л. Падение Каффы. Известия Таврической ученой архивной комиссии. 1918. № 54. С. $129-171$.

22. Колли Л. Хаджи-Гирей хан и его политика (по генуэзским источникам). Взгляд на политические сношения Каффы с татарами в XV веке. Известия Таврической ученой архивной комиссии. 1913. № 50. С. 99-139.

23. Колли Л. Христофоро ди Негро, последний консул Солдайи. Последние годы генуэзской Солдайи (1469-1475 гг.). Известия Таврической ученой архивной комиссии. 1905. № 38. С. 1-28.

24. Летописи белорусско-литовские. Полное собрание русских летописей. 1980. Т. 35. С. 19-84.

25. Летопись Авраамки. Полное собрание русских летописей. 1980. Т. 35. С. 85-90.

26. Мурзакевич Н. Молдо-Влахийские грамоты, хранящиеся в Бессарабии. Записки Одесского общества истории и древностей. 1848. № 2. С. 562-567.

27. Мыц В. Война 1433-1441 гг. между Каффой и Феодоро. Античная древность и средние века. 2000. № 31. С. 330-359.

28. Опимах О. Коллекция генуэзско-татарских аспров в собрании национального заповедника «София Киевская». Сугдейский сборник. Вып. ІІ. Киев-Судак, 2005. С. 524-528.

29. Степаненко В. Владетели Феодоро и византийская аристократия XV в. Античная древность и средние века. 2001. № 32. С. 335-353.

30. Степаненко В. Легенда о Гаврах и Херсонес в русской и советской историографии. Историография Балканского средневековья. Тверь, 1990. С. 87-95.

31. Талызина А. Баллистарии на венецианских галеях Романии. Византийский временник. 1999. № 58. C. 60-71.

32. Талызина А. Типология и эволюция формуляра документов по истории навигации. Причерноморье в средние века. 1998. № 3. С. 164-177.

33. Тизенгаузен В. Сборник материалов, относящихся к истории Золотой орды. СПб., 1884. Т. 1. 308 с.

34. Фомичев Н. Джучидские монеты из Азова. Советская археология. 1981. № 1. С. 219-241.

35. Чиперис А. К истории чембальского восстания. Ученые записки Туркменского университета. 1961. № 19. C. 291-307.

36. Agosto A. Due lettere inedite sugli eventi dei Cembalo e di Sorgati en Grimee nel 1434. Atti della Società Ligure di Storia Patria. Nuova Serie. 1977. № 17 (91). P. 513-517.

37. Agosto A. Nuovi reperti archivistici genovesi dell" «Officium Provisionis Romanie» sulla guerra di Cembalo (1434). Byzantino-bulgarica. 1981. № 7. P. 103-108.

38. Andreescu S. Autour de la derniere phase des rapports entre la Moldavie et Genes. Revue Roumaine d'Histoire. 1983. № 21. P. 257-271. 
39. Andreescu S. New documents relating to Carlo Lomellino's expedition in the Black Sea are (1434). Il Mar Nero. 2006. № 5. P. 259-272.

40. Archivio di Stato di Genova, Archivio Segreto 3034, Diversorum, Filze 14, No 2/6.

41. Archivio di Stato di Genova, Archivio Segreto 3037, Diversorum, Filze, 17, No 24.

42. Archivio di Stato di Genova, San Giorgio, Sala 34, 590/1230. Massaria Caffe 1422, f. 209v.

43. Archivio di Stato di Venezia, Senato, Misti, reg. 40, ff. 5 [6] v, 36 [37] v; reg. 43, ff. [203r], 207r; reg. 58, ff. 133r-v, 65r-v, 69r-v; reg. 59, ff. 42v, 52r-53v, 112r-v, 158r-159v; 164r-v, 166v; reg. 60, ff. 8r-v, 133v.

44. Babinger F. Maometto il Conquistatore e il suo tempo. Turin: Giulio Einaudi, 1957. 795 p.

45. Barker J. Manuel II Palaologus (1391-1425); A Study in Late Byzantine Statesmanship. New Brunswick/ New Jersey, 1969. 614 p.

46. Chalkokondyles L. Historiarum demonstrationes, ed. J. Darko, vol. 2. Budapest, 1927. 219-220.

47. Codex epistolaris Vitoldi Magni ducis Lithuaniae 1376-1430; coll. Opera Antonii Prochaska. Krakow, 1882. X, 688 (doc. 1181), 660 (doc. 1159), 721 (doc. 1223). 1113 p.

48. Cronaca di Anonimo Veronese. Cronice 1446-1488, edita la prima volta ed illustrata da Giovanni Soranzo. Monumenti storici publicati dellar. Deputazione Veteta di Storia Patria. Venezia: a spese della Società, 1915. 655 p.

49. Daru P. Histoire de la République de Venise, vol. 8. Paris, 1821. 666 p.

50. Długosz J. Joannis Długossii seu Longini canonici Cracoviensis Historiae Polonicae libri XII. Krakow, 1877, vol. 4.773 p.

51. Doumerc B. La crise structurelle de la marine vénitienne au XV siècle: le problème du retard des Mude. Annales ESC. 1985. C. 605-623.

52. Doumerc B. Les Vénitiens à la Tana au XVe siècle. Le Moyen Age. 1988. No. 3-4. P. 363-379.

53. Ducas. Corpus scriptorum historiae Byzantinae. Ed. B.G. Niebur. Bonn, 1834.

54. Dupuigrenet Desroussilles F. Vénitiens et Génois à Constantinople et en Mer Noire en 1431. Cahiers du Monde russe et soviétique. 1979. № 20/1. P. 111-122.

55. Ecthesis chronica, Chronicon Athenarum, ed. S. Lambros. London: 1902. 18.19-20; 33.15. Ibid. Chronicle 58,1 section 18 line 2. Ibid. Chronicle 37, 2 section 12 line 1 (12).

56. Folieta U. Thesaurus antiquitatum et historiarum Italiae. Leiden, 1704.

57. Gaina A. Astronomy, Geodesy and Map-Drawing in Moldova Since the Middle Ages Till the World War I. Serbian Astronomical Journal. 2001. № 162. P. 121-125.

58. Georgii et Johannis Stellae Annales Genuenses. Milan, 1730.

59. Giustiniani A. Annali della Repubblica di Genova. Genoa, 1537.

60. Halecki O. Z Jana Zamoyskiego Inwentarza Archivum Koronnego: Materiały do dziejlów Rusi i Litwy w XV wieku; Polska Akademia Umiejętności, Kraków. Archiwum Komisji Historycznej. Krakow, 1919. vol. 12: Cz. 1, S. 146-218.

61. Hankins J. Renaissance Crusaders Humanist Crusade Literature in the Age of Mehmed II. Dumbarton Oaks Papers. 1995. № 49 (Symposium on Byzantium and the Italians, 13th-15th Centuries). P. 111-207.

62. Ioan Bogdan. Documéntele lui Stefan eel Mare. Bucharest: Atelierele Grafice \& C, 1913. vol. 2. P. 324-328.

63. Jorga N. Notes et extraits pour servir à l'histoire des Croisade au XVe siècle. Revue de l'Orient latin. 1899. № 7.

64. Karpov S. "The Black Sea region before and after the IV crusade". Urbs capta: The Fourth Crusade and its Consequences; La IVe Croisade et ses conséquences. Paris, 2005. P. 285-294.

65. Cazacu M., Kévonian K. La chute de Caffa en 1475. La chute de Caffa en 1475 à la lumière de nouveaux documents. Cahiers du Monde russe et soviétique. 1976. № 17 (4). P. 495-538.

66. Kronika polska, litewska, żmódzka i wszystkiéj Rusi Maciejá Stryjkowskiego. Warsaw, 1846. vol. 2. 568 p.

67. Lannoy G. de. Voyages et ambassades de messire Guillebert de Lannoy, 1399-1450. Mons, 1840. 140 p.

68. Laurent V. L'assassinat d'Alexis IV empereur de Trébizonde (+1429): Date et circonstances. Archeion Pontou. 1955. № 20. P. 138-143.

69. Liv-, Est und Kurlandisches Urkundenbuch. Riga/Moscow, 1884. 687 p.

70. Małowist M. Kaffa - kolonia genuenska na Krymie i problem wschodni w latach 1453-1475. Prace Instytutu Historycznego Uniwersytetu Warszawskiego 2. Warsaw: University Press, 1947. 364 p.

71. Negri T. de. Storia di Genova. Florence, 2003. 846 p.

72. Nicol D. Byzantium and Venice: A Study in Diplomatic and cultural relations. Cambridge: Cambridge University Press, 1988. 465 p.

73. Olgiati G. The Genoese Colonies in Front of the Turkish Advance (1453-1475). Ankara Üniversitesi Dil ve Tarih-Coğrafya Fakültesi Tarih Bölümü Tarih Araştırmaları Dergisi. 1991. № 15/26. P. 381-389.

74. Pistarino G. The Genoese in Pera — Turkish Galata. Mediterranean Historical Review. 1986. № 1/1. P. 63-85.

75. Primaudaie É. Études sur le commerce au Moyen Age. Histoire du commerce de la mer Noire et des colonies génoises de la Krimée. Paris: Comptoir des imprimeurs-unis, 1848. 404 p. 
76. Régestes des délibérations du Sénat de Venise concernant la Romanie, vol. 3, 1431-1463, ed. Thiriet. Paris/ The Hague, Mouton \& Co., 1961. 276 p.

77. Roccatagliata A. Notai Genovesi in Oltremare: atti rogati a Pera e Miliene. Genova: Univ. di Genova, Ist. di Medievistica, 1982. $178 \mathrm{p}$.

78. Sathas K. Documents inédits relatifs à l'histoire de la Grèce au moyen âge. Paris, 1882. vol. 3. 344 p.

79. Spuler B. Die Goldene Horde. Die Mongolen in Russland 1223-1502. Leipzig, 1943. 556 s.

80. Stöckly D. Le Système de l'incanto des galées du marché de Venise (fin XIIIe - milieu XVe siècle). Leiden/ NY/Cologne, E. J. Brill, 1995. 434 p.

81. Tardy L. Régi magyar követjárások Keleten. Budapest: Akadémiai Kiadó, 1971. $221 \mathrm{~s}$.

82. Thiriet F. La Romanie vénitienne au moyen âge. Paris: Ed. Boccard, 1959. 193 p.

83. Vigna A. Codice diplomatico delle colonie Tauro-liguri. Genoa, 1868. 979 p.

\section{REFERENCES}

1. Agosto, A. (1977). Due lettere inedite sugli eventi dei Cembalo e di Sorgati en Grimee nel 1434. Atti della Società Ligure di Storia Patria. Nuova Serie, 17 (91), 513-517 [in Italian].

2. Agosto, A. (1981). Nuovi reperti archivistici genovesi dell” "Officium Provisionis Romanie» sulla guerra di Cembalo (1434). Byzantino-bulgarica, 7, 103-108. [in Italian].

3. Andreescu, S. (1983). Autour de la derniere phase des rapports entre la Moldavie et Genes. Revue Roumaine d'Histoire, 21, 257-271 [in French].

4. Andreescu, S. (2006). New Documents Relating to Carlo Lomellino's Expedition in the Black Sea are (1434). Il Mar Nero, 5, 259-272 [in English].

5. Archivio di Stato di Genova, Archivio Segreto 3034, Diversorum, Filze 14, No. 2 / 6.

6. Archivio di Stato di Genova, Archivio Segreto 3037, Diversorum, Filze, 17, No. 24.

7. Archivio di Stato di Genova, San Giorgio, Sala 34, 590/1230. Massaria Caffe 1422, f. 209v.

8. Archivio di Stato di Venezia, Senato, Misti, reg. 40, ff. 5 [6] v, 36 [37] v; reg. 43, ff. [203r], 207r; reg. 58, ff. 133r-v, 65r-v, 69r-v; reg. 59, ff. 42v, 52r-53v, 112r-v, 158r-159v; 164r-v, 166v; reg. 60, ff. 8r-v, 133v.

9. Babinger, F. (1957). Maometto il Conquistatore e il suo tempo. Turin: Giulio Einaudi [in Italian].

10. Baier, H.-F. (2001). Istoriia krymskikh gotov kak interpretatsiia Skazaniia Matfeia o gorode Feodoro. Ekaterinburg [in Russian].

11. Barker, J. (1969). Manuel II Palaologus (1391-1425); A Study in Late Byzantine Statesmanship. New Brunswick/New Jersey [in English].

12. Bertie-Delagard, A. L. (1920). Issledovanie nekotorykh nedoumennykh voprosov srednevekovia v Tavride. Izvestiia Tavricheskoi uchenoi arkhivnoi komissii, 57, 1-135 [in Russian].

13. Blizniuk, S. (1998). Koshelek i zhizn genueztsev v Konstantinopole i Adrianopole v seredine XV v. Prichernomorie v sredniie veka, 3, 126-144 [in Russian].

14. Bogdan, I. (1913). Documéntele lui Stefan cel Mare. Bucharest: Atelierele Grafice \& C, 324-328 [in Romanian].

15. Brun, F. (1872). Atlante idrografico del medio evo posseduto dal prof. Tammar-Luxoro, publisato a facsimile e annotalo dai socii C. Desimoni e L. Belgrano. Zapiski odesskogo obshhestva istorii i drevnostej, 8, 289-300 [in Italian].

16. Cazacu, M., \& Kévonian, K. (1976). La chute de Caffa en 1475. La chute de Caffa en 1475 à la lumière de nouveaux documents. Cahiers du Monde russe et soviétique, 17 (4), 495-538 [in French].

17. Chalkokondyles, L. (1927). Historiarum demonstrationes. Budapest [in Latin].

18. Chiperis, A. (1961). K istorii chembalskogo vosstaniia. Uchenyie zapiski Turkmenskogo universiteta, 19, 291-307 [in Russian].

19. Codex epistolaris Vitoldi Magni ducis Lithuaniae 1376-1430; coll. Opera Antonii Prochaska. Krakow, 1882. X, 688 (doc. 1181), 660 (doc. 1159), 721 (doc. 1223). 1113 p. [in Latin].

20. Cronaca di Anonimo Veronese. Cronica 1446-1488, edita la prima volta ed illustrata da Giovanni Soranzo. Venezia: a spese della Società, 1915 [in Latin].

21. Daru, P. (1821). Histoire de la République de Venise. Vol. 8, Paris [in French].

22. Długosz, J. (1877). Joannis Długossii seu Longini canonici Cracoviensis Historiae Polonicae libri XII. Krakow. [in Latin].

23. Doumerc, B. (1985). La crise structurelle de la marine vénitienne au XV siècle: le problème du retard des Mude. Annales ESC, 40/3, 605-623 [in French].

24. Doumerc, B. (1988). Les Vénitiens à la Tana au XVe siècle. Le Moyen Age, No. 3-4, 363-379 [in French].

25. Ducas (1834). Corpus scriptorum historiae Byzantinae. Bonn. [in Greek and Latin].

26. Dupuigrenet Desroussilles, F. (1979). Vénitiens et Génois à Constantinople et en Mer Noire en 1431. Cahiers du Monde russe et soviétique, 20/1, 111-122 [in French].

27. Ecthesis chronica, Chronicon Athenarum, ed. S. Lambros. London: 1902. [in Greek]. 
28. Emanov, A. (1995). Sever i Jug v istorii kommertsii na materialakh Kafy XIII-XV vv. Tiumen [in Russian].

29. Folieta, U. (1704). Thesaurus antiquitatum et historiarum Italiae. Leiden [in Latin].

30. Fomichev, N. (1981). Dzhuchidskie monety iz Azova. Sovetskaia arkheologiia, 1, 219-241 [in Russian].

31. Gaina, A. (2001). Astronomy, Geodesy and Map-Drawing in Moldova Since the Middle Ages Till the World War I. Serbian Astronomical Journal, 162, 121-125 [in English].

32. Georgii et Johannis Stellae Annales Genuenses. (1730). Milan [in Latin].

33. Georgii Sfrandzi. (1953). Bolshaia hronika. Vizantiiskii vremennik, 3 [in Russian].

34. Gercen, A. G. (2004). Moldaviia i kniazhestvo Feodoro v 1475 g. Antichnaia drevnost i srednie veka, 35, 226-241 [in Russian].

35. Giustiniani, A. (1537). Annali della Repubblica di Genova. Genova [in Italian].

36. Gramota Iliasha voievody i gospodaria Moldavskogo Vladislavu koroliu Polskomu 1434 goda, sentiabria. Zapiski odesskogo obshhestva istorii i drevnosti, 1860, 4, 323-330 [in Russian].

37. Grekov, I. (1963). Ocherki po istorii mezhdunarodnykh otnoshenii Vostochnoi Yevropy v XIV-XVI vv., M.: Izdatelstvo vostochnoi literatury [in Russian].

38. Grekov, I. (1975). Vostochnaia Yevropa i upadok Zolotoi Ordy (na rubezhe XIV-XV vv.). M.: Nauka [in Russian].

39. Halecki, O. (1919). Z Jana Zamoyskiego Inwentarza Archivum Koronnego: Materiały do dziejlów Rusi i Litwy w XV wieku; Polska Akademia Umiejętności, Kraków. Archiwum Komisji Historycznej. Krakow [in Polish].

40. Hankins, J. (1995). Renaissance Crusaders Humanist Crusade Literature in the Age of Mehmed II. Dumbarton Oaks Papers, 49 (Symposium on Byzantium and the Italians, 13th-15th Centuries), 111-207 [in English].

41. Jorga, N. (1899). Notes et extraits pour servir à l'histoire des Croisade au XVe siècle. Revue de l'Orient latin, 7 [in French].

42. Karpov, S. (2005). “The Black Sea Region Before and after the IV Crusade”. Urbs capta: The Fourth Crusade and its Consequences; La IVe Croisade et ses conséquences. Paris, 285-294 [in English].

43. Karpov, S. (2009). Greki i latiniane v venetsianskoi Tane (seredina 14-seredina 15 vv.). Prichernomorie $v$ sredniie veka, 7, 164-173 [in Russian].

44. Karpov, S. (1990). Italianskie morskie respubliki i Yuzhnoie Prichernomorie v XIII-XV vekakh: problemy torgovli, Moscow [in Russian].

45. Karpov, S. (1995). Prichernomorie v XV veke po materialam sobraniia Diversorum, Filze Sekretnogo Arhiva Genui. Prichernomorie v sredniie veka, 2, 9-19 [in Russian].

46. Karpov, S. (1994). Putiami srednevekovykh morekhodov. Moscow [in Russian].

47. Karpov, S. (1998). Regesty dokumentov fonda Diversorum Filze sekretnogo arkhiva Genui, otnosiashchiesia $\mathrm{k}$ istorii Prichernomoria. Prichernomorie v srednie veka, 3, 9-81 [in Russian].

48. Klimanov, L. (2005). Krymskie pamiatniki srednevekovoi genuezskoi lapidarnoi epigrafiki: vozmozhnosti istochnika. Sugdeiskii sbornik, 2, 454-484 [in Russian].

49. Kolli, L. (1913). Hadzhi-Girei khan i yego politika (po genuezskim istochnikam). Vzgliad na politicheskiie snosheniia Kaffy s tatarami v XV veke, Izvestiia Tavricheskoi uchenoi arkhivnoi komissii, 50, 99-139 [in Russian].

50. Kolli, L. (1905). Hristoforo di Negro, poslednii konsul Soldai. Poslednie gody genuezskoi Soldai (14691475 gg.). Izvestiia Tavricheskoi uchenoi arkhivnoi komissii, 38, 1-28 [in Russian].

51. Kolli, L. (1911). Istoricheskiie dokumenty o padenii Kaffy, Izvestiia Tavricheskoi uchenoi arkhivnoi komissii, 45, 1-24 [in Russian].

52. Kolli, L. (1911). Kaffa v period vladeniia yeiu bankom sv. Georgiia (1454-1475), Izvestiia Tavricheskoi uchenoi arkhivnoi komissii, 47, 75-112 [in Russian].

53. Kolli, L. (1918). Padenie Kaffy. Izvestiia Tavricheskoi uchenoi arkhivnoi komissii, 54, 129-171 [in Russian].

54. Kozubovskii, G. A. (2005). O vremeni poiavleniia kafinskikh nadchekanok na dzhuchidskikh monetakh. Sugdeiskii sbornik, 2, 155-160 [in Russian].

55. Kronika polska, litewska, żmódzka i wszystkiéj Rusi Maciejá Stryjkowskiego. Warsaw, 1846 [in Polish].

56. Lannoy, G. de. (1840). Voyages et ambassades de messire Guillebert de Lannoy, 1399-1450. Mons [in French].

57. Laurent, V. (1955). Lassassinat d’Alexis IV empereur de Trébizonde (+1429): Date et circonstances. Archeion Pontou, 20, 138-143 [in French].

58. Letopis Avraamki. (1980). Polnoie sobranie russkikh letopisei, 35, 85-90 [in Russian].

59. Letopisi Belorussko-Litovskie. (1980). Polnoie sobranie russkikh letopisei, 35, 19-84 [in Russian].

60. Liv-, Est und Kurlandisches Urkundenbuch. Riga/Moscow, 1884 [in German].

61. Małowist, M. (1947). Kaffa - kolonia genuenska na Krymie i problem wschodni w latach 1453-1475. Warsaw [in Polish].

62. Murzakevich, N. (1848). Moldo-Vlakhiiskie gramoty, khraniashchiesia v Bessarabii. Zapiski odesskogo obshchestva istorii i drevnostei, 2, 562-567 [in Russian]. 
63. Myts, V. (2000). Voina 1433-1441 gg. mezhdu Kaffoi i Feodoro. Antichnaia drevnost i srednie veka, 31, 330-359 [in Russian].

64. Negri, T. de. (2003). Storia di Genova. Florence [in Italian].

65. Nicol, D. (1988). Byzantium and Venice: A Study in Diplomatic and Cultural Relations. Cambridge: Cambridge University Press [in English].

66. Olgiati, G. (1991). The Genoese Colonies in Front of the Turkish Advance (1453-1475). Ankara Üniversitesi Dil ve Tarih-Coğrafya Fakültesi Tarih Bölümü Tarih Araştırmaları Dergisi, 15/26, 381-389 [in English].

67. Opimakh, O. (2005). Kollektsiia genuezsko-tatarskikh asprov v sobranii natsionalnogo zapovednika «Sofiia Kievskaia». Sugdeiskii sbornik, 2, 524-528 [in Russian].

68. Pistarino, G. (1986). The Genoese in Pera - Turkish Galata. Mediterranean Historical Review, 1/1, 63-85 [in English].

69. Primaudaie, É. (1848). Études sur le commerce au Moyen Age. Histoire du commerce de la mer Noire et des colonies génoises de la Krimée. Paris: Comptoir des imprimeurs-unis [in French].

70. Régestes des délibérations du Sénat de Venise concernant la Romanie, vol. 3, 1431-1463. Paris/The Hague, Mouton \& Co., 1961 [in French].

71. Roccatagliata, A. (1982). Notai Genovesi in Oltremare : atti rogati a Pera e Miliene. Genova: Univ. di Genova, Ist. di Medievistica [in Italian].

72. Sathas, K. (1882). Documents inédits relatifs à l'histoire de la Grèce au moyen âge. Paris [in French].

73. Spuler, B. (1943). Die Goldene Horde. Die Mongolen in Russland 1223-1502. Leipzig [in German].

74. Stepanenko, V. (1990). Legenda o Gavrakh i Khersones v russkoi i sovetskoi istoriografii. Istoriografiia Balkanskogo srednevekovia, 87-95 [in Russian].

75. Stepanenko, V. (2001). Vladeteli Feodoro i vizantiiskaia aristokratiia XV v. Antichnaia drevnost $i$ srednie veka, 32, 335-353 [in Russian].

76. Stöckly, D. (1995). Le Système de l'incanto des galées du marché de Venise (fin XIIIe - milieu XVe siècle). Leiden/NY/Cologne, E. J. Brill [in French].

77. Talyzina, A. (1999). Ballistarii na venetsianskikh galeiakh Romanii. Vizantiiskii vremennik, 58, 60-71 [in Russian].

78. Talyzina, A. (1998). Tipologiia i evoljutsiia formuliara dokumentov po istorii navigatsii. Prichernomorie $v$ srednie veka, 3, 164-177 [in Russian].

79. Tardy, L. (1971). Régi magyar követjárások Keleten. Budapest: Akadémiai Kiadó, 221 S. [in Hungarian].

80. Thiriet, F. (1959). La Romanie vénitienne au moyen âge. Paris: Ed. Boccard [in French].

81. Tizengauzen, V. (1884). Sbornik materialov, otnosiashchikhsia $k$ istorii Zolotoi ordy, T. 1, St. Petersburg [in Russian].

82. Vigna, A. (1868). Codice diplomatico delle colonie Tauro-liguri. Genova [in Latin].

83. Volkov, M. (1872). Chetyre goda goroda Kafy (1453, 1454, 1455 i 1456). Zapiski odesskogo obshchestva istorii i drevnostei, 8, 109-144 [in Russian].

Дата надходження статті до редакиії: 15.07.2019. 